\title{
Behavioral Influences on Crowdfunding SDG Initiatives: The Importance of Personality and Subjective Well-Being
}

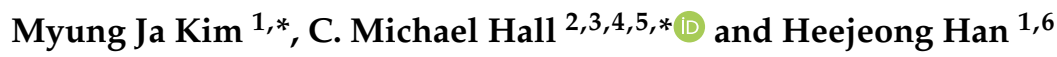 \\ 1 College of Hotel \& Tourism Management, Kyung Hee University, Seoul 02247, Korea; hjhan@kcti.re.kr \\ 2 Department of Management, Marketing, and Entrepreneurship, University of Canterbury, \\ Christchurch 8140, New Zealand \\ 3 Geography Research Unit, University of Oulu, 90014 Oulu, Finland \\ 4 Ekonomihögskolan, Linnéuniversitet, Universitetskajen, Landgången 6, 39182 Kalmar, Sweden \\ 5 Department of Service Management and Service Studies, Lund University, Campus Helsingborg, \\ 25108 Helsingborg, Sweden \\ 6 Korea Culture \& Tourism Institute, Seoul 07511, Korea \\ * Correspondence: silver@khu.ac.kr (M.J.K.); michael.hall@canterbury.ac.nz (C.M.H.); \\ Tel.: +82-10-9035-2696 (M.J.K.)
}

check for updates

Citation: Kim, M.J.; Hall, C.M.; Han,

H. Behavioral Influences on

Crowdfunding SDG Initiatives: The Importance of Personality and Subjective Well-Being. Sustainability 2021, 13, 3796. https://doi.org/ $10.3390 /$ su13073796

Academic Editor: Douglas Cumming

Received: 2 March 2021

Accepted: 24 March 2021

Published: 30 March 2021

Publisher's Note: MDPI stays neutral with regard to jurisdictional claims in published maps and institutional affiliations.

Copyright: (c) 2021 by the authors. Licensee MDPI, Basel, Switzerland. This article is an open access article distributed under the terms and conditions of the Creative Commons Attribution (CC BY) license (https:// creativecommons.org/licenses/by/ $4.0 /)$.

\begin{abstract}
Crowdfunding is emerging as a significant means by which to finance and advance the 17 United Nations Sustainable Development Goals (SDGs). Generating financial support for the SDGs is now of even more importance because of the economic impacts of COVID-19. However, little research on sustainability crowdfunding has been conducted, particularly with respect to how behavioral influences, such as personality and subjective well-being, affect the willingness of individuals to financially support the different SDGs. To fill this gap, a theoretically comprehensive research model including the big five personality traits typology, value on SDGs, attachment to sustainability crowdfunding, subjective well-being, and three groups of SDGs was constructed and tested. Results reveal that agreeableness has the highest effect on value on SDGs among five personalities, followed by openness and conscientiousness. Unexpectedly, extraversion has a negative impact on value on SDGs and neuroticism has an insignificant effect on value on SDGs. Value on SDGs has a great effect on attachment, followed by subjective well-being. Attachment has the greatest effect on subjective well-being within this research model. Comparing fair distribution, efficient allocation, and sustainable scale groups of SDGs shows substantial differences with respect to the hypotheses.
\end{abstract}

Keywords: sustainability crowdfunding; big five personality traits; SDG values; attachment; subjective well-being; COVID-19

\section{Introduction}

Sustainability has become a focal point for information and communications technology (ICT) research on human behavior [1,2]. In one sense this is perhaps not surprising given that the United Nations (UN) [3] regards ICT as indispensable in achieving its Sustainable Development Goals (SDGs) [4,5]. One critical area for this role is with respect to the development of innovative funding mechanisms for SDG related initiatives [6-8]. Such financial innovations have become even more important given the global economic, social and environmental impacts of the COVID-19 pandemic on sustainability and the SDGs $[9,10]$. One potential response, among the range of innovative digital technology initiatives that aim to contribute to sustainable development [11,12], is public crowdfunding via online platforms and technologies $[13,14]$. Crowdfunding via Internet platforms has been found to be a positive development for specific sustainability initiatives [15-18]. However, despite the growing significance of crowdfunding for sustainability, no studies have specifically examined crowdfunding in relation to the SDGs and especially the key 
factors that influence individual investors sustainability crowdfunding behavior. Given that there are 17 different SDGs, identifying the relative interest of crowdfunding investors in supporting different types of SDG would appear to be a substantial contribution to better understanding the role of ICT in sustainability and the achievement of the SDGs. In order to bridge this gap, this study builds and tests a conceptual framework regarding the role of funders' big five personality traits on sustainability value and attachment relevant to subjective well-being with moderators of SDG related crowdfunding as shown in Figure 1.

\section{Moderators of three SDG groups (fair distribution, efficient} allocation, and sustainable scale)

Big five personalities

(- Openness

- Conscientiousness

- Extraversion

- Agreeableness

- Neuroticism)

Antecedent

Mediators

Subjective wellbeing on sustainability crowdfunding

Dependent variable

Figure 1. Conceptual framework.

The big five personality traits (openness, conscientiousness, extraversion, agreeableness, and neuroticism) play critical roles in personal sustainability initiatives [19-21]. The big five personality traits have well explained various non-sustainability related aspects of crowdfunding sponsorship [22,23] and entrepreneurial behavior [24]. Each big five personality trait is relevant to particular individual value positions [25-28]. However, little research on personality has been conducted on perceived funder value of sustainability crowdfunding. Therefore, a significant research question in the context of SDG crowdfunding is: How distinctively do the big five personality traits influence crowdfunder value with respect to the SDGs (i.e., perceived ethics and pro-social behavior)?

Consumers' values have substantial impacts on their attachment to persons, organizations, products, and/or services [29,30], including their sustainability [31]. Individuals' values are also substantially and directly related to their subjective well-being for life satisfaction [32-34]. Mock et al. [35] have shown that psychological wellbeing (e.g., subjective well-being) is a significant aspect of people engaged in sustainability initiatives. Nevertheless, studies on sustainable crowdfunding have largely neglected the causes and effects of value, attachment, and subjective well-being. Accordingly, a second research question in SDG crowdfunding environments is: How distinctively does value on SDGs influence attachment to sustainability crowdfunding as well as subjective well-being?

People's attachment plays a crucial role in their subjective well-being in terms of sustainability initiatives [35,36], information technology [37], and adult attachment styles [38,39]. Yet, despite its significance, research on the relationship between attachment and subjective well-being has not been undertaken in SDG crowdfunding settings. Hence, a third research question in terms of SDG crowdfunding ventures is: Does funders' (e.g., supporters) attachment to sustainability crowdfunding influence their subjective well-being? 
The UN SDGs [3] can be categorized into three sub-clusters: fair distribution (protecting capabilities for flourishing), efficient allocation (building a living economy), and sustainable scale (staying within planetary boundaries) that reflect an Ecological Economics framework and the essential elements of sustainability [30,40,41]. Due to the lack of knowledge with respect to the different levels of support that crowdfunding investors have for the three SDG groups, research on the moderating effects of the three groups on crowdfunding behavior would be valuable for understanding the wider potential for crowdfunding to support SDG initiatives. Therefore, this study divides the 17 UN SDGs into the three groups and proposes a fourth research question: Do the fair distribution, efficient allocation, and sustainable scale SDG groups differ with respect to crowdfunder behavior?

In order to answer the four research questions, we have built and verified a theoretically integrated research model incorporating big five personality traits, value on SDGs, attachment to sustainability crowdfunding, subjective well-being, and three SDGs groups as moderators. In sum, the purpose of this study is to better understand the roles of personality, value, attachment, subjective well-being, and SDGs to enhance sustainability crowdfunding. Consequently, this study provides theoretical and practical implications for SDG crowdfunding as an information technology tool to promote sustainability.

\section{Literature Review}

\subsection{Theoretical Framework}

\subsubsection{Crowdfunding}

Crowdfunding can be defined as fundraising by different forms of "crowdsourcing, where individuals or organizations outsource special tasks, such as recruiting investors or donors who will support creative ideas for the benefits of personal or organizational activities" [42] (p. 312). Digital innovations in information technology have contributed to the emergence of crowdfunding between funders (investors) and founders (entrepreneurs) undertaken on online platforms [43-46]. Research on crowdfunding has well documented the characteristics and personalities of entrepreneurs and their relevance to project campaigns $[18,23,24,47,48]$. Similarly, studies have been undertaken on the role of investor's personality traits and their effect on the support of crowdfunding projects $[22,49,50]$. However, despite the importance of personality in crowdfunding behavior, there is little knowledge of the role of supporters' personalities in relation to sustainability crowdfunding initiatives. Therefore, this research explores the causes and effects of the big five personality traits of backers of three types of SDG crowdfunding using the constructs of value, attachment, and subjective well-being.

\subsubsection{Sustainability Crowdfunding}

The need to fulfill the SDGs is serving to normalize a dramatic shift in development finance [51]. Traditional donor contributions in the form of foreign aid/Official Development Assistance (ODA) have been supplemented by calls for greater private finance; capital markets; public-private partnership; diaspora-related investment and remittances; investment from insurance, pensions and philanthropic institutions; and other new financial measures [51-53]. For example, crowdfunding has become an increasingly important source of finance for new alternative energy technologies, although cleantech crowdfunding is more common in countries with low levels of individualism and more common when oil prices are rising [52]. Nevertheless, Cumming et al. point out the need for further research in this area [52]. The importance of developing a better understanding of crowdfunding sustainability initiatives has only become more urgent given the effects of COVID-19 on progress toward the SDGs [10], although even before COVID-19, the financing gap to achieve the SDGs by 2030 was estimated to be US $\$ 2.5$ trillion per year [54]. As a result, innovative approaches to the sourcing of private capital are required, especially "to encourage participation from untapped private sources" [9] (p. 1).

An increasing number of financial technology (Fintech) enterprises have launched innovative digital services to assist small and medium-sized enterprises (SMEs) avoid 
organizational barriers that may negatively impact the voluntary adoption of sustainable business models [55]. Fintech has also played an important role in the relationship between sustainable development and technological innovations on peer-to-peer online platforms [56], especially in the provision of electronic payment infrastructure which is integral to SDG related crowdfunding [57].

The appropriate use of digital technology is regarded as one of the potential pathways towards a sustainable socio-technical transition [12] and is especially important for enabling innovative financial responses, such as crowdfunding via online platforms, to be able to help close the SDG funding gap [58]. For example, digital platforms of crowdfunding sites (e.g., Goteo.org) facilitate financial support from individuals for SDG-related initiatives through crowdfunding and match-funding campaigns [18,59]. Drawing upon the emerging literature on novel private investment responses to the SDG funding gap and sustainability related crowdfunding, this study considers crowdfunding as a potentially useful ICTmediated tool to help finance SDGs related initiatives in the COVID-19 pandemic era.

\subsubsection{Personality Theory}

Personality theory refers to "a framework for formulating and testing hypotheses relating individual differences in personality to a wide range of criteria" [60] (p. 23). For instance, personality and leadership characteristics of individuals involved in policy entrepreneurship differ significantly from their counterparts in sustainability transitions of health care, water management, and regional development [21]. Compared to more stable personality traits, empathy is a promising area for intervention with the goal of increasing connectedness to nature and valuing of the environment in a sustainability perspective [19]. Moreover, the big five personality traits (i.e., openness, conscientiousness, extraversion, agreeableness, neuroticism) have substantially predicted environmental sustainability concerns at individual and country levels [20].

Crowdfunding scholars have become interested in the big five personality traits in order to better predict stakeholder behavior [22-24]. The personality traits of openness and agreeableness have been found to be the main drivers of success in both the adoption and diffusion of crowdfunding campaigns, while conscientiousness and extraversion solely support diffusion, but neuroticism is detrimental for adoption and diffusion [24]. Of the big five personality traits, the conscientiousness personality trait of entrepreneurs was found to have a significant effect on the use of social crowdfunding platforms [24]. Despite the implications of personality for sustainability initiatives [61] as well as crowdfunding, research on the big five personality traits has been largely overlooked on sustainability crowdfunding. Thus, this study aims to investigate the impact of funders' big five personality traits on value on SDGs relevant to attachment and subjective well-being in the context of SDG crowdfunding.

\subsubsection{Ethics and Pro-Social Behavior as Value on SDGs}

Ethics have long been recognized as a core element of the values that underly sustainable development [11,61,62]. Burford et al. [63] even suggest that ethical values should be regarded as a core "fourth pillar" of sustainability / sustainable development. Ethical values are expressions of, or beliefs in, the worth of objects, qualities, or behaviors in SDGs [62]. Research has also found that individual ethical support for sustainable development is related to both personality traits [61] and support for innovation [11].

Pro-social behavior means "altruistic giving, cooperation, and judgments in sacrificial moral dilemmas" in a public environment; including online environments, in which reputation is likely to be highly valued [64] (p. 1). Pro-social behavior also elaborates the roles of non-hedonistic values held by people [65]. However, few studies have given consideration as to how concern for one's social image may affect online pro-social activity, particularly in terms of sustainability crowdfunding via online platforms [43]. As campaign supporters are not only interested in a monetary return on investment but also personal ethical satisfaction and other pro-social motivations [48], therefore pro-social behavior with 
respect to sustainability crowdfunding is likely to be an important value with respect to the SDGs $[66,67]$. Based on the literature review, this study regards value on SDGs as a reflective second order factor with two sub-constructs of perceived ethics and pro-social behavior on SDGs in sustainability crowdfunding environments.

\subsubsection{Attachment}

Attachment has been defined as "the tendency of human beings to make solid affectional bonds to particular people and objects, explaining many forms of personality disturbance including anxiety, anger, depression, and emotional detachment" [68] (p. 201). Internet use has been shown to differ substantially according to attachment styles [37]. In reward-based crowdfunding, funder attachment to a project plays a main role in determining potential funders' intentions to invest in a project [44]. In tourism online crowdfunding ventures, sponsor attachment to fundraisers and platforms has a significant impact on participation [69]. Research has also found that online site attachment is an important mediator between value and trust as well as altruism and loyalty in ecommerce situations [29]. Drawing upon the literature review, this study considers attachment as a mediator in the proposed research model.

\subsubsection{Subjective Well-Being}

Subjective well-being displays moderately high levels of cross-situational consistency and temporal stability and is defined as people's longer-term levels of pleasant affect, lack of unpleasant affect, and life satisfaction [70]. That is, what ordinary people experience as happiness [71]. From a perspective of sustainability welfare economics, subjective wellbeing includes "life satisfaction, happiness, and a combined life satisfaction and happiness index" in the context of sustainable development $[71,72]$. The most material aspects are not associated with a higher level of individual subjective well-being; on the contrary, the most materialistic people are those who revealed lower levels of happiness as well as associated socioeconomic and environmental sustainability [73,74]. Sustainability and subjective well-being are also strongly interrelated domains, especially environmental aspects of sustainability, such as biodiversity conservation, with connectedness to nature being positively correlated with subjective well-being and sustainable behavior [75].

In an ICT context, subjective well-being is extremely significant with respect to mobile social media use and is a powerful predictor for consumer behavior [76]. In a virtual reality context, the development of high subjective well-being from virtual reality use necessarily leads to consumers' positive behavior to use information technologies in the future [77]. In ICT, users' subjective well-being is highly influenced by innovation attributes to the extent that their behavior is more affected by subjective well-being than authentic technological experience [78]. This study therefore takes subjective well-being as a target variable in SDG crowdfunding initiatives.

\subsection{Hypotheses Development}

Social-psychology research has long been interested in the relationships between personalities and values [25-28]. Agreeableness has been found to strongly positively correlate with benevolence and tradition values, openness with self-direction and universalism values, extroversion with achievement and stimulation values, and conscientiousness with achievement and conformity values [27]. The intellect trait of personality is related to order values (order, neatness, and responsibility) for males and social power values (power, prestige, and fame) for females [25]. Among students, agreeableness and extraversion was found to positively correlate with social orientation value; conscientiousness positively correlates with educational orientation value; and openness to experience negatively correlates with conformity and security value [26], emphasizing the relationship between personality and value. Interestingly, conscientiousness is related to pre- and post-training learning value, but none of the remaining the big five personality traits was found to be associated with post-training learning in a study of medical practices [28], implying that individuals 
can have different values depending on their personalities. Furthermore, Marcus and Roy [61] found that personality traits and core values were fundamental to sustainability actions, with personalities influencing values and sustainable practices. Nevertheless, there is no research on the relationships between the big five personality traits and values in terms of SDG crowdfunding. Accordingly, we propose the five following hypotheses:

Hypothesis 1 (H1). Openness significantly influences value on SDGs for sustainability crowdfunding.

Hypothesis 2 (H2). Conscientiousness significantly influences value on SDGs for sustainability crowdfunding.

Hypothesis 3 (H3). Extraversion significantly influences value on SDGs for sustainability crowdfunding.

Hypothesis 4 (H4). Agreeableness significantly influences value on SDGs for sustainability crowdfunding.

Hypothesis 5 (H5). Neuroticism significantly influences value on SDGs for sustainability crowdfunding.

Some researchers have identified a significant relationship between value and attachment in a variety of contexts [29-31]. For instance, in terms of World Heritage conservation, outstanding universal value (e.g., natural scenery, vegetation landscape, ecological environment) has a significant impact on place attachment in relation to sustainable developments [31]. Consumers' perceived functional, symbolic, hedonic, and sentimental values significantly influence hotel brand attachment, showing the mediating role of value [30]. From online tourism group-buying, the perceived value of an online grouping site's products or services significantly lead to attachment to the group buying site [29]. Furthermore, attachment to crowdfunding significantly mediates the relationship between source credibility and continued crowdfunding [69], implying that value can directly influence attachment. Therefore, this study posits the following hypothesis:

Hypothesis 6 (H6). Value on SDGs significantly influences attachment to sustainability crowdfunding.

Individual value orientations are systematically related to individual differences in subjective well-being, revealing that intra-individual changes in satisfaction are strongly influenced by the degree of individual values [32]. Well-being, a predictor of personal health and adjustment to environment, depends on the congruence between personal values and the prevailing value environment [25]. The holding of extrinsic or personally focused values is associated with lower levels of subjective well-being, and living in a country's largest metropolitan center has a negative effect on subjective well-being [32]. Achievement, self-direction, stimulation, tradition, conformity, and security values are closely associated with affective well-being, showing that subjective well-being depends upon congruence between personal values and the prevailing value environment [34]. Accordingly, we assume the following hypothesis:

Hypothesis 7 (H7). Value on SDGs significantly influences subjective well-being with sustainability crowdfunding.

In a cross-cultural study, the main predictor of subjective well-being for US and Portuguese respondents was attachment security [38]. Online users with a secure attachment style (i.e., attachment in this study) are significantly related to subjective well-being, while online users with preoccupied attachment style are negatively related to subjective wellbeing [37]. From both college student and community adult samples, subjective well-being was found to be negatively related to insecure attachment (i.e., anxiety and/or avoidance attachment), suggesting that secure attachment has a positive effect on subjective 
well-being [39]. In an online commerce context, attachment to the online site has substantial effects on altruism and loyalty to the site [29], suggesting that attachment influences subjective well-being. This study therefore proposes the following hypothesis:

Hypothesis 8 (H8). Attachment significantly influences subjective well-being with sustainability crowdfunding.

The three broad components of sustainability: fair distribution, efficient allocation, and sustainable scale are regarded as a means to combine the SDGs and their relationships to each other in modelling and measuring sustainable wellbeing [3,30,40,41]. In order to deal with resource scarcity without compromising human well-being, an ecosystem services approach suggests that the most emphasized aspects are related to the social equity of fair distribution, followed by environmental sustainability of sustainable scale, and resource flow of efficient allocation [30]. Therefore, based on Costanza et al. [40], this study categorizes the 17 UN SDGs as three groups of fair distribution (SDGs 1, 2, 3, 4, 5, 10, 16, and 17), efficient allocation (SDGs 7, 8, 9, 11, and 12), and sustainable scale (SDGs 6, 13,14 , and 15) in order to understand differences between the groups. Accordingly, we suggest the following hypothesis:

Hypothesis 9 (H9). Three SDG groups of fair distribution, efficient allocation, and sustainable scale have different impacts on the eight relationships in the research model.

The current study proposes an integrated comprehensive research model, with the intent of better understanding crowdfunders' personality, value, attachment, and subjective well-being in relation to SDG related crowdfunding. It suggests that the three groups of the 17 UN SDGs play a substantial moderating role. The proposed hypotheses are guided by past research which has been applied in different contexts. The resulting research model is displayed in Figure 2.

Comparing three groups by 17 sustainable development goals (fair distribution, efficient allocation, and sustainable scale SDG groups: $\left.\mathrm{H}_{9 \mathrm{a}} \sim \mathrm{H}_{9 \mathrm{~h}}\right)$

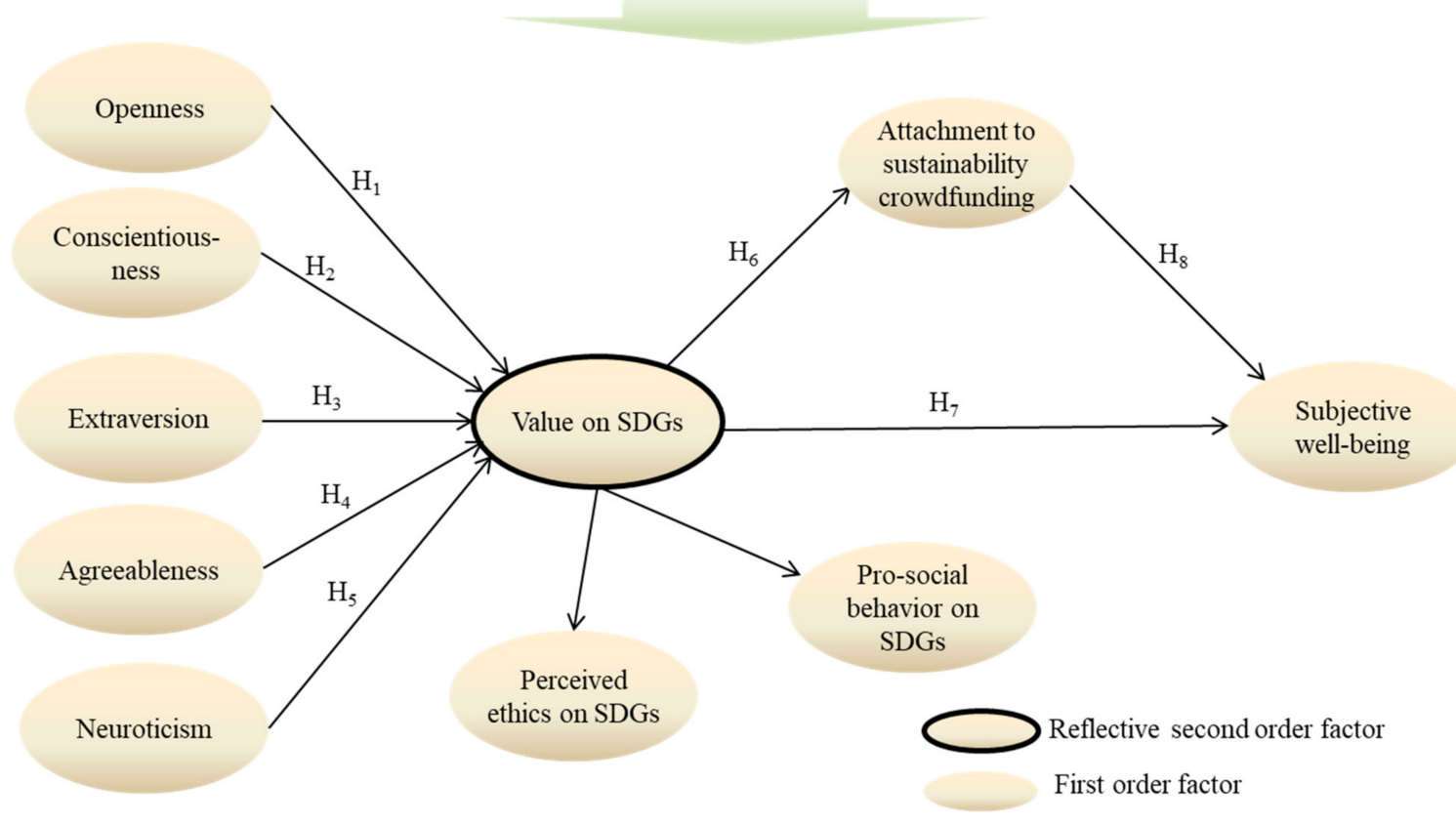

Figure 2. Research model. 


\section{Methods}

\subsection{Measurement}

This work employed an Internet survey of 45 items to assess nine constructs including: openness, conscientiousness, extraversion, agreeableness, neuroticism, perceived ethics on the SDGs, pro-social behavior on the SDGs, attachment to sustainability crowdfunding, and subjective well-being. All items have been adopted from previously validated scales reworded for sustainability related consumer behavior. To evaluate five personalities, five questions for each personality were derived from prior studies on sustainability or crowdfunding [19-22]. Each representative statement of openness, conscientiousness, extraversion, agreeableness, and neuroticism read as follows: "I get excited at new ideas," "I tend to implement my plans," "I talk to a lot of other people at parties," "I sympathize with the feelings of others," and "I get stressed out easily."

Five questions of perceived ethics on SDGs were derived from Burford et al. [63], Chen et al. [66] and Robert et al. [62], with an example statement being: "Walking or cycling to reduce $\mathrm{CO}_{2}$ emission helps the SDGs." Pro-social behavior on SDGs is evaluated by five questions based on Andersson et al. [64] and Weaver [65]. An example of pro-social behavior on SDGs is: "Participating in the SDGs is an ethically right action." The five items addressing attachment to sustainability crowdfunding were slightly modified from Bowlby [65], Herrero et al. [44], and Kim and Petrick [69], with an example statement being: "I have been deeply involved in participating in crowdfunding for sustainability." Five items related to subjective well-being were derived from previous literature [71,76-78], with an example statement being: "Financially supporting crowdfunding for sustainability is part of my ideal life." For grouping the 17 UN SDGs, fair distribution SDGs, efficient allocation SDGs, and sustainable scale SDGs were applied by Costanza et al. [40], Vinuesa et al. [5], and Zaini and Akhtar [79].

General information related to sustainability crowdfunding (participation length, overseas crowdfunding participation, used platforms, experienced types, frequency, investment amount, reason of sustainability crowdfunding, invested projects in the $17 \mathrm{UN}$ SDGs, characteristics of sustainability crowdfunding, non-crowdfunding for sustainability, and participated overseas projects in the SDGs) were included. Seven socio-demographic questions are also included in the survey instrument.

Importantly, sustainability in this study has been defined in terms of the 17 UN SDGs: to end poverty; reduce hunger; warrant healthy lives as well as well-being; ensure education; achieve gender equality; ensure water as well as sanitation; access to sustainable energy; promote decent employment; build resilient infrastructure; reduce inequality; ensure sustainable consumption; combat climate change; conserve oceans, seas, and marine resources; conserve terrestrial ecosystems; protect ecosystems; promote peaceful societies; and strengthen global partnership [3]. Defining sustainability-related crowdfunding in terms of the SDGs was regarded as providing a clear focus to the notion of sustainability in crowdfunding and may also shed light on the relative interest in different SDG categories [58].

The questions have been evaluated by seven-anchor Likert-types as they give high discriminant and reliability validity [80,81]. The original survey tool was in English, then translated into a Korean language version with the assistance of three language professionals fluent in both English and Korean. The instrument was then subsequently back-translated into English in order to check possible variations in meaning [82,83]. The translation process led to minor revisions in the Korean language version of the survey with respect to the concepts of personality, value on SDGs, and subjective well-being.

Three researchers familiar with crowdfunding and SDGs reviewed the content validity of the survey instrument. Three managers of SDG crowdfunding also evaluated the suitability of the questionnaire. Based on their feedback, one perceived ethics item, one pro-social behavior item, one attachment item, and one subjective well-being item were deleted due to overlapping meanings between items (i.e., "Seeking the SDGs brings better lives," "Participating in the SDGs is the right thing to do," "Investing in sustainability 
crowdfunding is important to me," and "So far, I have had the important things that I need by financially supporting sustainability crowdfunding"). Several items of openness, conscientiousness extraversion, agreeableness, and neuroticism were also edited to better capture meaning.

A pilot test was performed by five doctoral students who have experience in sustainability crowdfunding and who then provided further feedback to the researchers. As a result, four questions from perceived ethics on SDGs, pro-social behavior on SDGs, attachment to sustainability crowdfunding, and subjective well-being were revised. A pre-test was implemented on 50 people who had crowdfunded SDG related projects in Korea within the prior twelve-month time period with respondents requested to provide feedback on questions as appropriate. As a result of these steps, questions relating to the big five personality traits and general information items regarding to sustainability crowdfunding were revised for clarity (see questionnaire in Supplemental A).

\subsection{Data Collection}

Internet surveys are generally conducted because of speed of responses, target population access, and cost-effectiveness [84,85]. In Korea, an online survey is deemed to be appropriate because crowdfunding is undertaken through Internet sites [77]. In order to best manage the survey process, an online survey company, Embrain, was employed. The survey company has over 1.3 million Korean panel members and is the largest Internet survey firm in Korea. The company also strictly adheres to protocols to ensure reliability and validity of collecting data.

The online survey was conducted from 11 to 23 March 2020. The invitation to participate in the study was sent to 16,762 Korean panellists. This was because the online survey firm that was used generally gets useable questionnaires from an average of three per cent of panellists after the initial invitation to participate. It has also been suggested that multi-group analysis (MGA) models like the one applied in this study need over 400 cases for structural equation modeling (SEM) analysis to be used [86,87]. A quota sampling method was applied based on smartphone users by selection questions of age and gender (Supplemental A), and the sample was matched with the age and gender ratio of mobile Internet users in Korea (Supplemental B) [88].

Participants who successfully answered the selecting question (who had participated in SDG related crowdfunding in the previous year) were asked to provide a name of an SDG related crowdfunding venture that they had funded to support SDG projects as a backer or sponsor in the prior year (see SQ1 in Supplemental A). The SDG crowdfunding project stated by each respondent then appeared on each following question. The orders of questions on constructs were also rotated to reduce response bias. Participants who spent less than five seconds per item have not been included in the study because response times of less than five seconds per item tend to be associated with unreliable answers in Internet surveys [89]. In addition, automated procedures deleted respondents that answered too quickly or used repetitive patterns in their responses because it is likely that they did not fully read questions.

The email invitation was received by 4335 panelists and 4264 individuals opened the questionnaire. Following an introductory explanation as to the survey and the SDGs, each respondent had the selection item ("In the past 12 months, have you had any experience with crowdfunding for the 17 UN SDGs?"). From the 1380 qualified subjects who answered 'yes', 614 subjects went on to fully answer the survey. Once outliers as well as subjects who did not provide the name of the SDG crowdfunding project that they participated in were removed, 500 completed questionnaires were coded for analysis. Accordingly, the response rate is 36.2 percent as the final 500 respondents came from 1380 qualified panelists.

\subsection{Data Analysis}

In order to test the proposed research model, partial least squares (PLS)-SEM was applied. PLS-SEM has been argued as being more suitable for MGA and/or comprehensively 
integrated models than covariance-based (CB)-SEM approaches [90-92]. Consequently, SmartPLS 3.2.9 has been utilized [93] in this work. In order to confirm the moderating effects of high and low interventions in sustainability crowdfunding, we employed MGA according to the PLS-SEM analysis from Chin et al. [90] and Ringle et al. [93]. Furthermore, we have conducted two common method bias tests which show that common method bias is not a problem in this study (see Supplemental C).

\section{Results}

\subsection{Grouping Check}

A grouping has been operationalized by the screen question of participation in crowdfunding for the 17 UN SDGs. Based on Costanza et al. [40], three clusters appeared. That is, the first group names fair distribution crowdfunders for SDGs 1, 2, 3, 4, 5, 10, 16, and 17 with 211 cases. The second group names efficient allocation crowdfunders for SDGs 7, 8, 9, 11 , and 12 with 185 cases. The third group names sustainable scale crowdfunders for SDGs $6,13,14$, and 15 with 104 cases. According to the PLS algorithm, approximately 100 cases for each group is deemed to be suitable for MGA so the three groups are appropriate to compare to each other $[91,92]$.

\subsection{Respondents' Profile}

As shown in Table 1, while a majority of fair distribution (53.1\%) and sustainable scale subjects $(52.9 \%)$ were female, a comparatively larger majority of efficient allocation subjects $(56.8 \%)$ were male. The majority of the sample were in the 20-29 years old bracket for the fair distribution (25.2\%), in the 40-49 years old bracket for the efficient allocation (28.7\%), and in the 30-39 years old bracket for the sustainable scale groups (29.8\%). A majority of subjects have attended a university or higher in fair distribution (75.4\%), efficient allocation $(79.4 \%)$, sustainable scale groups $(74.1 \%)$. The majority of the fair distribution group are married $(52.7 \%)$, while the majority of the efficient allocation (56.8\%) and sustainable scale groups $(65.4 \%)$ are single. The majority of crowdfunders had a monthly family income of four million Korean Won (KRW) and over for fair distribution (72.5\%), efficient allocation $(65.9 \%)$, and sustainable scale subjects $(72.1 \%)$ (US\$ $1=$ KRW 1194). A majority of subjects have full time employment in the fair distribution (69.6\%), efficient allocation (81.7\%), and sustainable scale groups $(76.0 \%)$. The majority of the sample lived in metropolitan areas for the fair distribution $(66.0 \%)$, efficient allocation $(66.5 \%)$, and sustainable scale groups (67.3\%). The sustainable scale group appears to participate in more overseas crowdfunding, frequently participate in crowdfunding, and to sponsor more donation types. In contrast, the efficient allocation group appears to have longer experience in crowdfunding, to participate in more investment types, and to be bigger investors. In terms of the 17 SDGs, the respondents primarily participated in public health and well-being projects $(13.2 \%)$, followed by green business practices and employment $(9.2 \%)$, waste reduction and recycling $(9.0 \%)$, and poverty reduction (8.6\%). See more details in Table 1 for the three groups and Supplemental D for the entire group.

\subsection{Measurement Model}

Since an item was found to have non-normal distribution, as shown in Supplemental E, PLS-SEM was appropriate for data evaluation. Results of the measurement model have been presented in Supplemental F. Two neuroticism questions ("I am filled with doubts" and "I fall into a panic easily") received lower than a 0.5 factor loading (the sample size is 500 cases so we applied the cut off of 0.5). Accordingly, the two items have been removed [86,87]. As illustrated in Table 2,Cronbach's $\alpha$ as well as the Rho_A of constructs have larger than 0.70 , signifying that the concepts met internal consistency requirements [94]. Additionally, the average variance extracted (AVE) of concepts is greater than 0.5 , the composite reliability of each question greater than 0.7 , and the factor loadings of each item are larger than 0.5 [86], signifying convergent validity. 
Table 1. Demographic characteristic and general information of fair distribution (FD), efficient allocation (EA), and sustainable scale (SS) SDG groups.

\begin{tabular}{|c|c|c|c|c|c|c|c|}
\hline Characteristics & FD (\%) & EA (\%) & SS (\%) & Characteristics & FD (\%) & EA (\%) & SS (\%) \\
\hline Gender & & & & Experienced types ** & & & \\
\hline Male & 46.9 & 56.8 & 47.1 & Donation & 54.0 & 44.9 & 54.8 \\
\hline Female & 53.1 & 43.2 & 52.9 & Reward & 64.0 & 64.9 & 69.2 \\
\hline Age & & & & Investment (stocks, bonds) & 35.5 & 51.9 & 30.8 \\
\hline Under 20 years old & 4.7 & 5.4 & 14.4 & Lending & 14.7 & 24.3 & 18.3 \\
\hline 20-29 years old & 25.2 & 25.9 & 26.9 & Other & 0.9 & 0.0 & 0.0 \\
\hline 30-39 years old & 23.7 & 25.9 & 29.8 & Frequency of crowdfunding & & & \\
\hline 40-49 years old & 24.6 & 28.7 & 21.2 & Monthly or more frequently & 54.5 & 52.5 & 54.8 \\
\hline $50-59$ years old & 16.6 & 11.4 & 7.7 & Quarterly or less frequently & 45.5 & 47.5 & 45.2 \\
\hline 60 years old and over & 5.2 & 2.7 & 0.0 & Investment amount & & & \\
\hline Educational level & & & & Less than $100,000 \mathrm{KRW}$ & 62.9 & 55.1 & 70.1 \\
\hline $\begin{array}{l}\text { Less than or high school } \\
\text { diploma }\end{array}$ & 15.6 & 14.1 & 19.2 & From 100,000 to $999,999 \mathrm{KRW}$ & 31.9 & 35.2 & 27.0 \\
\hline 2-year college & 9.0 & 6.5 & 6.7 & $1,000,000 \mathrm{KRW}$ or more & 5.2 & 9.7 & 2.9 \\
\hline University & 59.8 & 59.9 & 58.7 & $\begin{array}{l}\text { Frequency of sustainability } \\
\text { crowdfunding }\end{array}$ & & & \\
\hline Graduate school or higher & 15.6 & 19.5 & 15.4 & Monthly or more frequently & 44.5 & 41.0 & 43.3 \\
\hline Marital status & & & & Quarterly or less frequently & 55.4 & 59.0 & 56.7 \\
\hline Single & 44.5 & 56.8 & 65.4 & $\begin{array}{l}\text { Investment amount for } \\
\text { sustainability }\end{array}$ & & & \\
\hline Married & 52.7 & 42.7 & 34.6 & Less than $100,000 \mathrm{KRW}$ & 72.1 & 63.8 & 78.9 \\
\hline $\begin{array}{l}\text { Divorce, separate, or } \\
\text { widow/er }\end{array}$ & 2.8 & 0.5 & 0.0 & From 100,000 to $999,999 \mathrm{KRW}$ & 24.2 & 32.0 & 20.1 \\
\hline Monthly household income & & & & $1,000,000 \mathrm{KRW}$ or more & 3.7 & 4.2 & 1.0 \\
\hline Less than 2.00 million $\mathrm{KRW}^{*}$ & 5.7 & 2.7 & 1.0 & $\begin{array}{l}\text { Reason for sustainability } \\
\text { crowdfunding }\end{array}$ & & & \\
\hline From 2.00 to 3.99 million KRW & 21.8 & 31.4 & 26.9 & Donation & 34.6 & 15.7 & 37.5 \\
\hline From 4.00 to 5.99 million KRW & 24.6 & 25.9 & 32.7 & Reward & 41.8 & 40.5 & 43.3 \\
\hline From 6.00 to 7.99 million KRW & 20.4 & 18.9 & 17.3 & Investment (stocks, bonds) & 17.5 & 34.6 & 15.4 \\
\hline $\begin{array}{l}\text { From } 8.00 \text { to over million } \\
\text { KRW }\end{array}$ & 27.5 & 21.1 & 22.1 & Lending & 5.2 & 9.2 & 3.8 \\
\hline Occupation & & & & Other & 0.9 & 0.0 & 0.0 \\
\hline Professionals & 12.3 & 18.9 & 11.5 & $\begin{array}{l}\text { Participated projects in the } \\
17 \text { SDGs }\end{array}$ & & & \\
\hline Business owner & 5.2 & 8.6 & 5.8 & $\begin{array}{l}\text { 1. Poverty reduction } \\
\text { 2. Reducing }\end{array}$ & 20.4 & & \\
\hline Service worker & 3.3 & 5.4 & 1.0 & $\begin{array}{l}\text { hunger/sustainable } \\
\text { agriculture/food }\end{array}$ & 10.9 & & \\
\hline Office worker & 42.2 & 46.6 & 54.8 & $\begin{array}{l}\text { 3. Public health and } \\
\text { well-being }\end{array}$ & 31.3 & & \\
\hline Civil servant & 6.6 & 2.2 & 2.9 & $\begin{array}{l}\text { 4. Ensure equitable quality } \\
\text { education for all }\end{array}$ & 4.7 & & \\
\hline Home maker & 10.0 & 3.8 & 1.0 & 5. Achieve gender equality & 10.4 & & \\
\hline Retiree & 0.5 & 0.5 & 0.0 & $\begin{array}{l}\text { 6. Clean water and } \\
\text { public sanitation }\end{array}$ & & & 21.2 \\
\hline Student & 13.7 & 11.9 & 19.2 & $\begin{array}{l}\text { 7. Ensure access to } \\
\text { sustainable energy }\end{array}$ & & 14.6 & \\
\hline Unemployed & 2.4 & 1.6 & 1.9 & $\begin{array}{l}\text { 8. Green business } \\
\text { practices/employment }\end{array}$ & & 24.9 & \\
\hline Other & 3.8 & 0.5 & 1.9 & $\begin{array}{l}\text { 9. Build resilient } \\
\text { infrastructure }\end{array}$ & & 22.7 & \\
\hline
\end{tabular}


Table 1. Cont

\begin{tabular}{|c|c|c|c|c|c|c|c|}
\hline Characteristics & FD (\%) & EA (\%) & SS (\%) & Characteristics & FD (\%) & EA (\%) & SS (\%) \\
\hline Residential district & & & & $\begin{array}{l}\text { 10. Reduce inequality } \\
\text { within/among countries }\end{array}$ & 9.5 & & \\
\hline Metropolitan areas & 66.0 & 66.5 & 67.3 & $\begin{array}{l}\text { 11. Build resilient and } \\
\text { sustainable cities }\end{array}$ & & 13.5 & \\
\hline Non-metropolitan areas & 34.0 & 33.5 & 32.7 & $\begin{array}{l}\text { 12. Waste reduction } \\
\text { and recycling }\end{array}$ & & 24.3 & \\
\hline Participation length & & & & $\begin{array}{l}\text { 13. Urgent action on } \\
\text { climate change }\end{array}$ & & & 20.2 \\
\hline Less than 7 months & 44.5 & 42.8 & 53.7 & $\begin{array}{l}\text { 14. Conserve marine } \\
\text { ecosystems }\end{array}$ & & & 22.1 \\
\hline 7 or more months & 55.5 & 57.2 & 46.3 & $\begin{array}{l}\text { 15. Conserve terrestrial } \\
\text { ecosystems }\end{array}$ & & & 36.5 \\
\hline Overseas funding & & & & $\begin{array}{l}\text { 16. Promote peaceful } \\
\text { societies/reduce violence }\end{array}$ & 8.1 & & \\
\hline Yes & 20.4 & 17.3 & 25.0 & $\begin{array}{l}\text { 17. Strengthen global } \\
\text { partnership }\end{array}$ & 4.7 & & \\
\hline No & 79.6 & 82.7 & 75.0 & $\begin{array}{l}\text { Characteristics of } \\
\text { sustainability crowdfunding }\end{array}$ & & & \\
\hline $\begin{array}{l}\text { Overseas sustainability } \\
\text { funding }\end{array}$ & & & & Profit crowdfunding project & 36.5 & 51.9 & 23.1 \\
\hline Yes & 14.2 & 10.3 & 14.4 & $\begin{array}{l}\text { Non-profit crowdfunding } \\
\text { project }\end{array}$ & 46.4 & 27.6 & 53.8 \\
\hline No & 85.8 & 89.7 & 85.6 & Don't know & 17.1 & 20.5 & 23.1 \\
\hline Used platforms & & & & $\begin{array}{l}\text { Non-crowdfunding } \\
\text { for sustainability }\end{array}$ & & & \\
\hline OhMyCompnay & 10.9 & 8.1 & 3.8 & Yes & 14.2 & 10.3 & 14.4 \\
\hline Wadiz & 38.4 & 59.5 & 42.4 & No & 85.8 & 89.7 & 85.6 \\
\hline Crowdy & 7.6 & 7.0 & 4.8 & $\begin{array}{l}\text { Participated overseas } \\
\text { projects in the } 17 \text { SDGs }\end{array}$ & & & \\
\hline Tumblebug & 8.5 & 5.4 & 20.2 & $\begin{array}{l}\text { Fair distribution (SDGs } 1,2,3 \text {, } \\
4,5,10,16,17 \text { ) }\end{array}$ & 46.7 & 36.8 & 26.7 \\
\hline HappyBean & 24.6 & 11.9 & 24.0 & $\begin{array}{l}\text { Efficient allocation (SDGs } 7,8 \text {, } \\
9,11,12 \text { ) }\end{array}$ & 33.3 & 57.9 & 20.0 \\
\hline Other & 10.0 & 8.1 & 4.8 & $\begin{array}{l}\text { Sustainable scale (SDGs } 6,13 \text {, } \\
14,15 \text { ) }\end{array}$ & 20.0 & 5.3 & 53.3 \\
\hline
\end{tabular}

Note: The FD, EA, and SS SDG groups have 211, 185, and 104 respondents, respectively. ** Multiple choice item.

Table 2. Reliability and discriminant validity (Heterotrait-Monotrait Ratio $<0.9$ ).

\begin{tabular}{|c|c|c|c|c|c|c|c|c|c|}
\hline \multirow{2}{*}{ Construct } & \multicolumn{9}{|c|}{ Correlation of the Constructs } \\
\hline & 1 & 2 & 3 & 4 & 5 & 6 & 7 & 8 & 9 \\
\hline \multicolumn{10}{|l|}{ 1. Openness } \\
\hline 2. Conscientiousness & 0.640 & & & & & & & & \\
\hline 3. Extraversion & 0.649 & 0.668 & & & & & & & \\
\hline 4. Agreeableness & 0.688 & 0.703 & 0.789 & & & & & & \\
\hline 5. Neuroticism & 0.168 & 0.110 & 0.101 & 0.132 & & & & & \\
\hline 6. Perceived ethics on SDGs & 0.425 & 0.346 & 0.210 & 0.477 & 0.069 & & & & \\
\hline 7. Pro-social behavior on SDGs & 0.481 & 0.498 & 0.364 & 0.604 & 0.076 & 0.639 & & & \\
\hline $\begin{array}{l}\text { 8. Attachment to } \\
\text { sustainability crowdfunding }\end{array}$ & 0.319 & 0.475 & 0.430 & 0.442 & 0.094 & 0.286 & 0.499 & & \\
\hline 9. Subjective well-being & 0.347 & 0.503 & 0.373 & 0.458 & 0.069 & 0.735 & 0.600 & 0.759 & \\
\hline Cronbach's alpha $\geq 0.7$ & 0.849 & 0.821 & 0.830 & 0.757 & 0.768 & 0.870 & 0.836 & 0.910 & 0.881 \\
\hline Rho_A (reliability coefficient) $\geq 0.7$ & 0.859 & 0.825 & 0.872 & 0.792 & 0.781 & 0.871 & 0.846 & 0.913 & 0.881 \\
\hline Composite reliability $\geq 0.7$ & 0.892 & 0.875 & 0.875 & 0.833 & 0.841 & 0.911 & 0.891 & 0.937 & 0.918 \\
\hline $\mathrm{AVE} \geq 0.5$ & 0.625 & 0.583 & 0.584 & 0.632 & 0.515 & 0.720 & 0.672 & 0.788 & 0.736 \\
\hline Effect size $\left(Q^{2}\right)>0$ & & & & & & 0.544 & 0.521 & 0.120 & 0.367 \\
\hline
\end{tabular}


The Heterotrait-Monotrait (HTMT) value was utilized to examine discriminant validity (Hair et al., 2017). It is recommended that the HTMT value is the more precise standard for investigating discriminant validity (lower than 0.90) than generally applied Fornell and Larcker [95]. Since all HTMT values were less than 0.9 in Table 2, there is substantial support for the measurement framework to have met conditions of discriminant validity (Hair et al., 2017) [91]. Q2 figures of greater than zero from endogenous constructs were identified. These results signify an appropriate assessment standard for cross-validated prediction [96,97].

\subsection{Structural Model}

Figure 3 displays the findings of the PLS-SEM that evaluated the hypothesised relationships [93]. For the three endogenous constructs, the variance explained $\left(\mathrm{R}^{2}\right)$ are: value on SDGs (32.1\%), attachment to sustainability crowdfunding (15.6\%), and subjective well-being $(51.7 \%)$. The evaluated t-statistics and path coefficients have been applied for the relationships by PLS bootstrapping (5000 resamplings) [90,92,94].

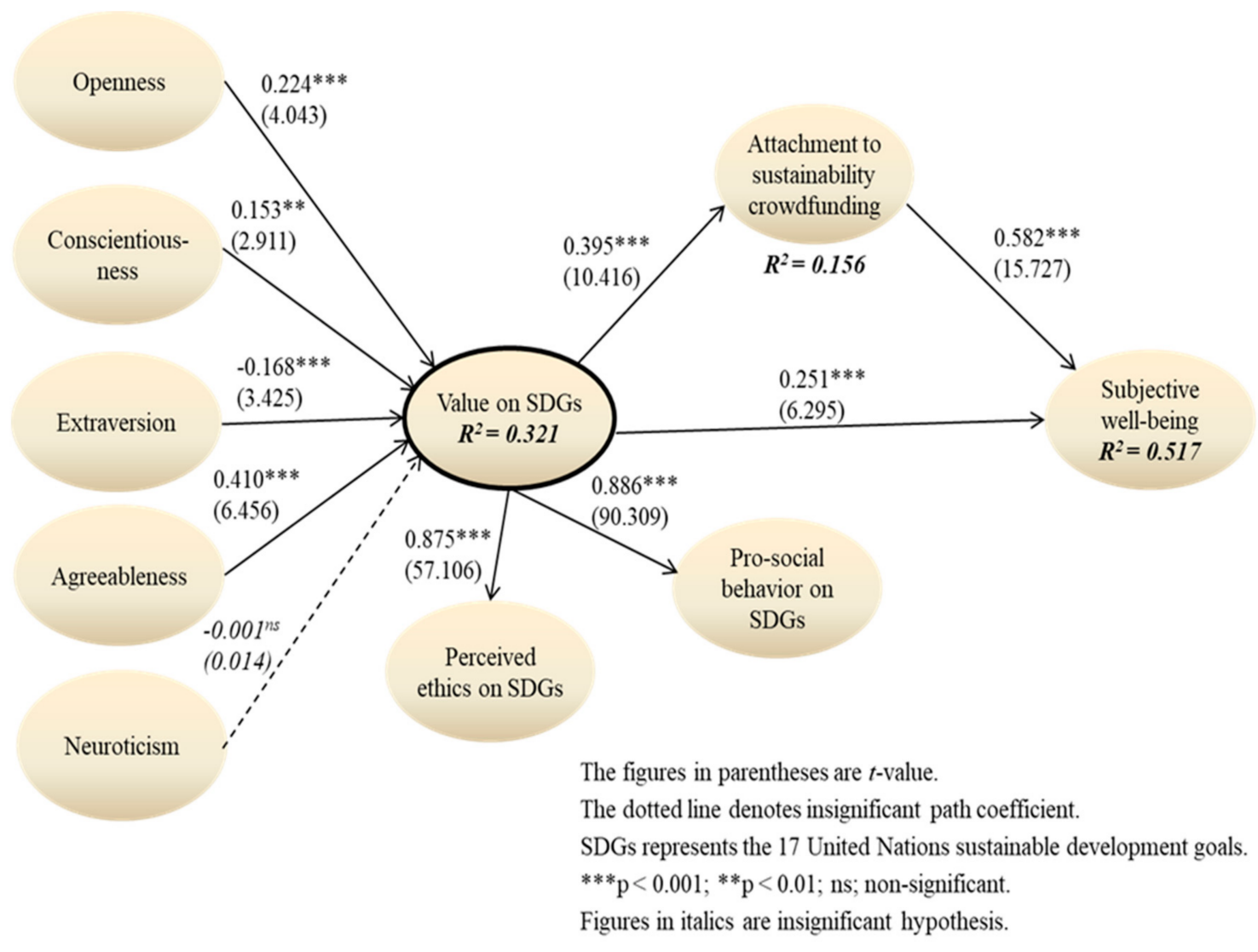

Figure 3. Path analysis results.

The findings revealed that value on SDGs has been influenced by openness $(\gamma=0.224$, $\mathrm{t}$-value $=4.043, p<0.001)$, conscientiousness $(\gamma=0.153$, $\mathrm{t}$-value $=2.911, p<0.01)$, extraversion $(\gamma=-0.168, \mathrm{t}$-value $=3.425, p<0.001)$, and agreeableness $(\gamma=0.410, \mathrm{t}$-value $=6.456$, $p<0.001)$. Value on SDGs is found to have a positive effect on attachment to sustainability crowdfunding $(\beta=0.395$, $\mathrm{t}$-value $=10.416, p<0.001)$. Subjective well-being has been significantly influenced by value on SDGs $(\beta=0.251$, $\mathrm{t}$-value $=6.295, p<0.001)$ and attachment to sustainability crowdfunding $(\beta=0.582$, $\mathrm{t}$-value $=15.727, p<0.001)$. Hence, H1, H2, H3, H4, H6, H7, and H8 have been supported. However, the relationship between neuroticism and value on SDGs was insignificant $(\gamma=-0.001$, $\mathrm{t}$-value $=0.014, p>0.05)$, thus $\mathrm{H}_{5}$ was not been supported. With regard to two sub-constructs of the second-order construct, value on 
SDGs is highly relevant to perceived ethics on SDGs $(\lambda=0.875, \mathrm{t}$-value $=57.106, p<0.001)$ and pro-social behavior on SDGs $(\lambda=0.886$, $\mathrm{t}$-value $=90.309, p<0.001)$.

\subsection{Moderating and Mediating Roles}

Regarding the eight hypotheses, the moderating effect of the three SDG groups have been examined in Table 3. Variances among fair distribution, efficient allocation, and sustainable scale subjects are compared applying explained variance $\left(R^{2}\right)$ [87]. The three endogenous constructs of $\mathrm{R}^{2}$ are value on SDGs (fair distribution $=34.0 \%$; efficient allocation $=37.9$; sustainable scale $=29.3 \%$ ), attachment to sustainability crowdfunding (fair distribution $=16.8 \%$; efficient allocation $=13.3$; sustainable scale $=19.4 \%$ ), and subjective well-being (fair distribution $=50.8 \%$; efficient allocation $=57.0$; sustainable scale $=47.4 \%$ ), showing that the efficient allocation group has the highest explanatory power in value on SDGs and subjective well-being.

Table 3. Comparing fair distribution, efficient allocation, and sustainable scale SDGs.

\begin{tabular}{|c|c|c|c|c|c|}
\hline H9 & Group & Path Coefficient & t-Value & $p$-Value & Result \\
\hline \multirow{3}{*}{$\begin{array}{l}\text { H9a: Openness } \rightarrow \\
\text { Value on SDGs }\end{array}$} & Fair distribution & $0.259^{* *}$ & 3.089 & $<0.01$ & \multirow{3}{*}{$\begin{array}{l}\text { The sustainable scale group } \\
\text { has the highest positive effect. }\end{array}$} \\
\hline & Efficient allocation & $0.085^{n s}$ & 0.896 & $>0.05$ & \\
\hline & Sustainable scale & $0.338^{* * *}$ & 3.438 & $<0.001$ & \\
\hline \multirow{3}{*}{$\begin{array}{l}\text { H9b: Conscientiousness } \rightarrow \\
\text { Value on SDGs }\end{array}$} & Fair distribution & $0.127^{n s}$ & 1.614 & $>0.05$ & \multirow{3}{*}{$\begin{array}{l}\text { The efficient allocation group } \\
\text { has the highest positive effect. }\end{array}$} \\
\hline & Efficient allocation & $0.291^{* * *}$ & 3.673 & $<0.001$ & \\
\hline & Sustainable scale & $0.168^{n s}$ & 1.500 & $>0.05$ & \\
\hline \multirow{3}{*}{$\begin{array}{l}\text { H9c: Extraversion } \rightarrow \\
\quad \text { Value on SDGs }\end{array}$} & Fair distribution & $-0.230 *$ & 2.438 & $<0.05$ & \multirow{3}{*}{$\begin{array}{l}\text { The fair distribution group } \\
\text { has the highest negative effect. }\end{array}$} \\
\hline & Efficient allocation & $-0.114^{n s}$ & 1.313 & $>0.05$ & \\
\hline & Sustainable scale & $-0.224^{n s}$ & 1.829 & $>0.05$ & \\
\hline \multirow{3}{*}{$\begin{array}{l}\text { H9d: Agreeableness } \rightarrow \\
\quad \text { Value on SDGs }\end{array}$} & Fair distribution & $0.474^{* * *}$ & 4.727 & $<0.001$ & \multirow{3}{*}{$\begin{array}{l}\text { The fair distribution group } \\
\text { has the highest positive effect. }\end{array}$} \\
\hline & Efficient allocation & $0.415^{* * *}$ & 4.540 & $<0.001$ & \\
\hline & Sustainable scale & 0.285 * & 2.076 & $<0.05$ & \\
\hline \multirow{3}{*}{$\begin{array}{l}\text { H9e: Neuroticism } \rightarrow \\
\quad \text { Value on SDGs }\end{array}$} & Fair distribution & $-0.128^{n s}$ & 1.242 & $>0.05$ & \multirow{3}{*}{$\begin{array}{l}\text { All the three groups have } \\
\text { insignificant effects. }\end{array}$} \\
\hline & Efficient allocation & $0.009^{n s}$ & 0.118 & $>0.05$ & \\
\hline & Sustainable scale & $0.115^{n s}$ & 1.003 & $>0.05$ & \\
\hline \multirow{3}{*}{$\begin{array}{c}\text { H9f: Value on SDGs } \rightarrow \\
\text { Attachment to } \\
\text { sustainability crowdfunding }\end{array}$} & Fair distribution & $0.410^{* * *}$ & 7.303 & $<0.001$ & \multirow{3}{*}{$\begin{array}{l}\text { The sustainable scale group } \\
\text { has the highest positive effect. }\end{array}$} \\
\hline & Efficient allocation & $0.365^{* * *}$ & 5.518 & $<0.001$ & \\
\hline & Sustainable scale & $0.440^{* * *}$ & 5.384 & $<0.001$ & \\
\hline \multirow{3}{*}{$\begin{array}{l}\text { H9g: Value on SDGs } \rightarrow \\
\text { Subjective well-being }\end{array}$} & Fair distribution & $0.253^{* * *}$ & 3.879 & $<0.001$ & \multirow{3}{*}{$\begin{array}{l}\text { The efficient allocation group } \\
\text { has the highest positive effect. }\end{array}$} \\
\hline & Efficient allocation & $0.291^{* * *}$ & 4.993 & $<0.001$ & \\
\hline & Sustainable scale & $0.171^{n s}$ & 1.848 & $>0.05$ & \\
\hline \multirow{3}{*}{$\begin{array}{l}\text { H9h: Attachment to } \\
\text { sustainability Crowdfunding } \\
\rightarrow \text { Subjective well-being }\end{array}$} & Fair distribution & $0.571^{* * *}$ & 11.597 & $<0.001$ & \multirow{3}{*}{$\begin{array}{l}\text { The efficient allocation group } \\
\text { has the highest positive effect. }\end{array}$} \\
\hline & Efficient allocation & $0.599^{* * *}$ & 11.395 & $<0.001$ & \\
\hline & Sustainable scale & $0.596^{* * *}$ & 6.271 & $<0.001$ & \\
\hline
\end{tabular}

As shown in Table 3, from 24 relationships of three groups, 16 relationships are significant. In the fair distribution group, the six relationships between openness and value, extraversion and value, agreeableness and value, value and attachment, value and subjective well-being, and attachment and subjective well-being were significant. In the efficient allocation group, the five relationships between conscientiousness and 
value, agreeableness and value, value and attachment, value and subjective well-being, and attachment and subject well-being were significant. In the sustainable scale group, the four relationships between openness and value, agreeableness and value, value and attachment, and attachment and subjective well-being were significant.

The fair distribution group has the two highest relationships between extraversion and value $(\gamma=-0.230$, $\mathrm{t}$-value $=2.438, p<0.05: \mathrm{H} 3 \mathrm{a})$ and agreeableness and value $(\gamma=0.474$, $\mathrm{t}$-value $=4.727, p<0.001 ; \mathrm{H} 4 \mathrm{a})$ in the three groups. The efficient allocation group has the three highest relationships between conscientiousness and value $(\gamma=0.291$, $\mathrm{t}$-value $=3.673$, $p<0.001 ; \mathrm{H} 2 \mathrm{a})$, value and subjective well-being $(\beta=0.291$, $\mathrm{t}$-value $=4.993, p<0.001$ : H7a), and attachment and subjective well-being $(\beta=0.599$, $\mathrm{t}$-value $=6.271, p<0.001$ : H8a) from three groups. The sustainable scale group has the two highest positive relationships between openness and value $(\gamma=0.338$, t-value $=3.438, p<0.001 ; \mathrm{H} 1 \mathrm{a})$ and value and attachment $(\beta=0.440, \mathrm{t}$-value $=5.384, p<0.001$ : H6a) among three groups. The relationships between neuroticism and value (H5a) of all three groups are insignificant.

PLS bootstrap with 5000 re-samplings has been utilized to examine the mediating impacts of two mediators (value and attachment) in the study framework (Supplemental G). For example, attachment and subjective well-being have been positively indirectly influenced by openness, conscientiousness, and agreeableness. In addition, attachment and subjective well-being have been negatively indirectly influenced by extraversion. Moreover, the relationship between value on SDGs and subjective well-being has the highest indirect impact by the mediator of attachment $(\beta=0.230$, $\mathrm{t}$-value $=8.179, p<0.001)$ in the research model. However, the relationships between neuroticism and attachment as well as neuroticism and subjective well-being have insignificant indirect effects.

\section{Discussion and Conclusions}

\subsection{Discussion}

"Financing for development means ... mobilizing the resources necessary for sustainable development and specifically for success in the SDGs" [98] (p. 276). Crowdfunding is an innovative means of generating new private finance streams for the SDGs $[11,13,14,99]$, and providing digital solutions for SDGs-related initiatives $[15,16,52,58]$, which is particularly relevant given the economic impacts of COVID-19. However, little previous research has specifically looked at the behavior of sustainability-related crowdfunders. In order to fill this potentially significant research gap, this study shed light on factors influencing sustainable crowdfunder behavior in terms of personality, value, attachment, subjective-well-being, and the SDGs in an Asian context (i.e., South Korea).

The results reveal that agreeableness has the highest effect on value on SDGs among the five personalities, followed by openness and conscientiousness. The finding on agreeableness is consistent with results from previous literature that people having agreeableness characteristics are more likely to be positively related to the value types of benevolence and traditionalism [27]. This implies that crowdfunders with sympathy for others are more likely to have strong ethical beliefs on SDGs. Additionally, the results suggest that investors seeking a new idea tend to have high moral duty towards SDG crowdfunding which is consistent with prior research where openness to experience has been found to significantly predict environmental attitudes and behaviour [61]. Furthermore, the findings suggest that sponsors have goal-directed behaviors that support ethical values for SDG crowdfunding projects. This extends existing findings that conscientiousness strongly correlates with the values of responsibility [25]. Unexpectedly, and contrary to previous research [28], extraversion has a negative impact on value on SDGs. Neuroticism has an insignificant effect on values toward SDGs, which is partially consistent with previous findings [26]. In addition, value on the SDGs is more closely related to pro-social behavior than perceived ethics, suggesting that consumer behavioral beliefs are better indicators for SDG behavior than their ethical norms.

Value on the SDGs has a great effect on attachment, followed by subjective well-being, expanding the previous literature on the relationships among source credibility, attachment, 
contoured crowdfunding [69] and the impact of value on subjective well-being [43]. The results suggest, for example, that consumers who practice emission reduction are more likely to be involved in sustainability crowdfunding. Additionally, those who reduce waste tend to be satisfied with participating in sustainability crowdfunding. In addition, attachment highly positively influences subjective well-being, broadening the prior research on the effect of attachment on subjective well-being [39]. Not so surprisingly, backers who are highly attached to participating in sustainability crowdfunding appear to have greater satisfaction with SDG crowdfunding. Overall, the proposed research model in this study well predicts sustainable well-being for crowdfunders.

By comparing differences between the three SDG groups on the eight relationships in the research model, it was found that the efficient allocation group has the three largest positive impacts between conscientiousness and value, value and subjective well-being, and attachment and subjective well-being. The findings indicate that funders pursuing perfectionism place high value on building a living economy SDG projects; investors with high value on the SDGs tend to have great subjective well-being with net economic contribution projects among the SDGs; and sponsors with strong attachment to sustainability crowdfunding have great subjective well-being with efficient allocation SDGs. With regard to the fair distribution respondents, funders with higher extraversion appear more likely to have less value on SDGs, while funders with greater agreeableness seem more likely to have greater value on the SDGs. With the sustainable scale respondents, funders with higher openness appear more likely to have stronger value on the SDGs and funders with stronger value on SDGs tend more likely to have stronger attachment among the three groups, broadening prior research on staying within planetary boundaries [40] to include consideration of personal preferences in financially supporting the SDGs.

\subsection{Theoretical Implications}

This study provides several theoretical contributions to the literature on crowdfunding as a means of financing SDG initiatives and projects. For example, this study is the first theoretical attempt to examine the impact of the big five personality traits as antecedents on the value of sustainability in the context of SDG crowdfunding. The significantly positive effects of openness, conscientiousness, and agreeableness on value identified in this research extends the prior studies on the relationships between the big five personality traits and value [25-28]. In addition, value on SDGs and attachment to sustainability crowdfunding as mediators were found to have considerable roles in crowdfunder behavior in this study's theoretical model. The great impact of value on attachment also enlarges previous literature on the relationship between perceived values and brand attachment [30]. The effect of value on subjective well-being broadens past literature on the relationship between personal values and well-being [34].

Funders' subjective well-being was found to be the critical construct in SDG crowdfunding environments. Identification of the strong influence of attachment on subjective well-being in the research model strengthens the literature on the relationship between secure attachment and subjective well-being [37-39,76]. The result also highlights the need for researchers to be aware of the importance of funder subjective well-being in sustainability crowdfunding. Importantly, differences among the three SDG groups expand prior literature on the application of the fair distribution, efficient allocation, and sustainable scale groupings to include ICT enabled financing of the SDGs [30,40,41]. The findings therefore offer new insights in terms of the online financing of sustainability and SDG initiatives as well as the contribution of behavioural research on ICT to the SDGs [1,2].

\subsection{Practical Implications}

The findings of this work offer several online managerial contributions to SDG crowdfunding stakeholders. For example, in order to increase crowdfunders' value on SDGs, supportive crowdfunding platforms and SDG-related initiatives should be able to utilize potential funders' personality traits to create more effective marketing strategies. That is, if 
crowdfundraisers want to increase private SDGs-related investment, they should focus on investors with a high degree of agreeableness. This can be done by online promoting their sustainability crowdfunding projects in terms of highlighting sympathy, concern, respect, belief, and trust. The significant effect of openness on value also suggests that creators should build their website content to reflect such a consumer perspective on new ideas, thinking, and/or imaginations.

The great influence of value on attachment indicates that SDGs-initiatives seeking crowdfunder investment should try to facilitate funder attachment by boosting their perceived sustainability value. In order to enhance crowdfunders' subjective well-being, sustainability crowdfund creators should stress the value of the SDGs. This could possibly be undertaken by producing appropriate digital storytelling that compliments and supports SDG initiatives. However, the best way to reach funder subjective well-being is to stimulate potential investors' attachment. The differences among three SDG groups suggest that sustainability related crowdfunding should segment their markets by the fair distribution, efficient allocation, and sustainable scale categories. In other words, if crowdfundraisers target fair distribution SDGs, the fundraisers should focus on factors of extraversion, agreeableness, and value on SDGs. In contrast, when entrepreneurs want to obtain funds for efficient allocation SDGs, they should focus on factors of conscientiousness, value, attachment, and subjective well-being. When businesses want to seek funds for sustainable projects, they should focus on openness and attachment as psychological traits.

\subsection{Limitations and Future Research Directions}

Although this study has substantial theoretical and managerial implications for academics and practitioners, there are several limitations that offer opportunities for future research. First, this research was conducted on SDG crowdfunding only for Korean funders and it was conducted at the height of the COVID-19 pandemic on March 2020 in Korea. Accordingly, caution needs to be exercised in generalizing the findings of this research to different cultures, countries, and/or periods. Second, the survey was administered during the pandemic and some respondents participated in SDG crowdfunding for COVID-19 vaccine development projects, but no direct questions on the influence of COVID-19 on crowdfunding behavior were asked. Future research should therefore investigate the influence of the pandemic on crowdfunding as well as broader perceptions of the SDGs given the particular impacts of COVID-19 on health, well-being, biosecurity, and the economy.

Further research would be enhanced by utilizing different research methods from the present study to complement future surveys, such as big data analysis of social media and online/mobile websites and artificial intelligence analysis using public data in order to better understand sustainable crowdfunder behavior. Finally, future studies on the big five personality traits with entrepreneurs (e.g., crowdfounder, creators, fundraisers) for sustainability crowdfunding would be interesting to identify motivations to offer SDG projects for investment.

Supplementary Materials: The following are available online at https: / www.mdpi.com/article/ 10.3390/su13073796/s1, Supplemental A. Questionnaire, Supplemental B. Quota sampling based on gender and age, Supplemental C. Common method bias tests, Supplemental D. Demographic characteristic and general information of the entire group, Supplemental E. Descriptive statistics and normal distribution test, Supplemental F. Measurements, Supplemental G. Mediating effect.

Author Contributions: M.J.K. contributed to conducting the survey, collecting data, analyzing data, and writing the draft; C.M.H. contributed to developing the questionnaire, conceptualization of the research model, and writing and editing the manuscript; H.H. contributed to refining the questionnaire and provided invaluable comments on developing instruments and conducting the survey. All authors have read and agreed to the published version of the manuscript.

Funding: This work was supported by the Ministry of Education of the Republic of Korea and the National Research Foundation of Korea (NRF-2018S1A5A8026985).

Institutional Review Board Statement: Not applicable. 
Informed Consent Statement: Not applicable.

Data Availability Statement: The study did not report any data.

Conflicts of Interest: The authors declare no conflict of interest.

\section{References}

1. Mora, H.; Pujol-López, F.A.; Mendoza-Tello, J.C.; Morales-Morales, M.R. An Education-Based Approach for Enabling the Sustainable Development Gear. Comput. Hum. Behav. 2020, 107, 105775. [CrossRef]

2. Pan, S.L.; Zhang, S. From Fighting COVID-19 Pandemic to Tackling Sustainable Development Goals: An Opportunity for Responsible Information Systems Research. Int. J. Inf. Manag. 2020, 55, 102196. [CrossRef]

3. United Nations. Transforming Our World: The 2030 Agenda for Sustainable Development; United Nations: New York, NY, USA, 2015.

4. Goncalves, G.; Oliveira, T.; Cruz-Jesus, F. Understanding Individual-Level Digital Divide: Evidence of an African Country. Comput. Hum. Behav. 2018, 87, 276-291. [CrossRef]

5. Vinuesa, R.; Azizpour, H.; Leite, I.; Balaam, M.; Dignum, V.; Domisch, S.; Felländer, A.; Langhans, S.D.; Tegmark, M.; Fuso Nerini, F. The Role of Artificial Intelligence in Achieving the Sustainable Development Goals. Nat. Commun. 2020, 11, 1-10. [CrossRef] [PubMed]

6. Bebbington, J.; Unerman, J. Achieving the United Nations Sustainable Development Goals: An Enabling Role for Accounting Research. Account. Audit. Account. J. 2018, 31, 2-24. [CrossRef]

7. Khan, R. How Frugal Innovation Promotes Social Sustainability. Sustainability 2016, 8, 1034. [CrossRef]

8. Yuan, F.; Gallagher, K.P. Greening Development Lending in the Americas: Trends and Determinants. Ecol. Econ. 2018, 154, 189-200. [CrossRef]

9. Runde, D.F.; Metzger, C.; Abdullah, H.F. Covid-19 Demands Innovative Ideas for Financing the SDGs. Available online: https://www.csis.org/analysis/covid-19-demands-innovative-ideas-financing-sdgs (accessed on 19 July 2020).

10. Thornton, J. Covid-19 Pandemic Has Derailed Progress on Sustainable Development Goals, Says WHO. BMJ 2020, 369 , m1969. [CrossRef]

11. Cillo, V.; Petruzzelli, A.M.; Ardito, L.; Del Giudice, M. Understanding Sustainable Innovation: A Systematic Literature Review. Corp. Soc. Responsib. Environ. Manag. 2019, 26, 1012-1025. [CrossRef]

12. Wells, P.; Abouarghoub, W.; Pettit, S.; Beresford, A. A Socio-Technical Transitions Perspective for Assessing Future Sustainability Following the COVID-19 Pandemic. Sustain. Sci. Pract. Policy 2020, 16, 29-36. [CrossRef]

13. Lehner, O.M.; Harrer, T. Crowdfunding Revisited: A Neo-Institutional Field-Perspective. Ventur. Cap. 2019, 21, 75-96. [CrossRef]

14. Roma, P.; Messeni Petruzzelli, A.; Perrone, G. From the Crowd to the Market: The Role of Reward-Based Crowdfunding Performance in Attracting Professional Investors. Res. Policy 2017, 46, 1606-1628. [CrossRef]

15. Calic, G.; Mosakowski, E. Kicking off Social Entrepreneurship: How a Sustainability Orientation Influences Crowdfunding Success. J. Manag. Stud. 2016, 53, 738-767. [CrossRef]

16. Messeni Petruzzelli, A.; Natalicchio, A.; Panniello, U.; Roma, P. Understanding the Crowdfunding Phenomenon and Its Implications for Sustainability. Technol. Forecast Soc. Change 2019, 141, 138-148. [CrossRef]

17. Testa, S.; Roma, P.; Vasi, M.; Cincotti, S. Crowdfunding as a Tool to Support Sustainability-Oriented Initiatives: Preliminary Insights into the Role of Product/Service Attributes. Bus. Strateg. Environ. 2020, 29, 530-546. [CrossRef]

18. Vismara, S. Sustainability in Equity Crowdfunding. Technol. Forecast Soc. Change 2019, 141, 98-106. [CrossRef]

19. Di Fabio, A.; Kenny, M.E. Connectedness to Nature, Personality Traits and Empathy from a Sustainability Perspective. Curr. Psychol. 2018, 1-12. [CrossRef]

20. Hirsh, J.B. Environmental Sustainability and National Personality. J. Environ. Psychol. 2014, 38, 233-240. [CrossRef]

21. Timmermans, J.; Van Der Heiden, S.; Born, M.P. Policy Entrepreneurs in Sustainability Transitions: Their Personality and Leadership Profiles Assessed. Environ. Innov. Soc. Transit. 2014, 13, 96-108. [CrossRef]

22. Ryu, S.; Kim, Y.G. A Typology of Crowdfunding Sponsors: Birds of a Feather Flock Together? Electron. Commer. Res. Appl. 2016, 16, 43-54. [CrossRef]

23. Bernardino, S.; Santos, J.F. Financing Social Ventures by Crowdfunding: The Influence of Entrepreneurs' Personality Traits. Int. J. Entrep. Innov. 2016, 17, 173-183. [CrossRef]

24. Thies, F.; Wessel, M.; Rudolph, J.; Benlian, A. Personality Matters: How Signaling Personality Traits Can Influence the Adoption and Diffusion of Crowdfunding Campaigns. In Proceedings of the 24th European Conference on Information Systems, ECIS, Istanbul, Turkey, 12-15 June 2016.

25. Aluja, A.; García, L.F. Relationships between Big Five Personality Factors and Values. Soc. Behav. Pers. 2004, 32, 619-625. [CrossRef]

26. Poliach, V.; Salbot, V. The Relation between Big Five Personality Traits and the Personal Values of Youth. New Educ. Rev. 2011, 25, 319-333.

27. Roccas, S.; Sagiv, L.; Schwartz, S.H.; Knafo, A. The Big Five Personality Factors and Personal Values. Personal Soc. Psychol. Bull. 2002, 28, 789-801. [CrossRef]

28. Woods, S.A.; Patterson, F.C.; Koczwara, A.; Sofat, J.A. The Value of Being a Conscientious Learner: Examining the Effects of the Big Five Personality Traits on Self-Reported Learning from Training. J. Work. Learn. 2016, 28, 424-434. [CrossRef] 
29. Kim, M.J.; Chung, N.; Lee, C.K.; Preis, M.W. Online Group-Buying of Tourism Products: Effects of Value and Trust on Site Attachment, Altruism, and Loyalty. J. Travel Tour. Mark. 2015, 32, 935-952. [CrossRef]

30. Liu, S.; Costanza, R.; Farber, S.; Troy, A. Valuing Ecosystem Services: Theory, Practice, and the Need for a Transdisciplinary Synthesis. Ann. N. Y. Acad. Sci. 2010, 1185, 54-78. [CrossRef]

31. Nian, S.; Zhang, H.; Mao, L.; Zhao, W.; Zhang, H.; Lu, Y.; Zhang, Y.; Xu, Y. How Outstanding Universal Value, Service Quality and Place Attachment Influences Tourist Intention Towardsworld Heritage Conservation: A Case Study of Mount Sanqingshan National Park, China. Sustainability 2019, 11, 3321. [CrossRef]

32. Morrison, P.S.; Weckroth, M. Human Values, Subjective Well-Being and the Metropolitan Region. Reg. Stud. 2018, 52, 325-337. [CrossRef]

33. Oishi, S.; Diener, E.; Suh, E.; Lucas, R.E. Value as a Moderator in Subjective Well-Being. J. Pers. 1999, 67, 157-184. [CrossRef]

34. Sagiv, L.; Schwartz, S.H. Value Priorities and Subjective Well-Being: Direct Relations and Congruity Effects. Eur. J. Soc. Psychol. 2000, 30, 177-198. [CrossRef]

35. Mock, M.; Omann, I.; Polzin, C.; Spekkink, W.; Schuler, J.; Pandur, V.; Brizi, A.; Panno, A. “Something inside Me Has Been Set in Motion": Exploring the Psychological Wellbeing of People Engaged in Sustainability Initiatives. Ecol. Econ. 2019, $160,1-11$. [CrossRef]

36. Vita, G.; Ivanova, D.; Dumitru, A.; García-Mira, R.; Carrus, G.; Stadler, K.; Krause, K.; Wood, R.; Hertwich, E.G. Happier with Less? Members of European Environmental Grassroots Initiatives Reconcile Lower Carbon Footprints with Higher Life Satisfaction and Income Increases. Energy Res. Soc. Sci. 2020, 60, 101329. [CrossRef]

37. Odaci, H.; Çikrikçi, Ö. Problematic Internet Use in Terms of Gender, Attachment Styles and Subjective Well-Being in University Students. Comput. Hum. Behav. 2014, 32, 61-66. [CrossRef]

38. Galinha, I.C.; Oishi, S.; Pereira, C.R.; Wirtz, D.; Esteves, F. Adult Attachment, Love Styles, Relationship Experiences and Subjective Well-Being: Cross-Cultural and Gender Comparison between Americans, Portuguese, and Mozambicans. Soc. Indic. Res. 2014, 119, 823-852. [CrossRef]

39. Wei, M.; Liao, K.Y.H.; Ku, T.Y.; Shaffer, P.A. Attachment, Self-Compassion, Empathy, and Subjective Well-Being among College Students and Community Adults. J. Pers. 2011, 79, 191-221. [CrossRef]

40. Costanza, R.; Daly, L.; Fioramonti, L.; Giovannini, E.; Kubiszewski, I.; Mortensen, L.F.; Pickett, K.E.; Ragnarsdottir, K.V.; De Vogli, R.; Wilkinson, R. Modelling and Measuring Sustainable Wellbeing in Connection with the UN Sustainable Development Goals. Ecol. Econ. 2016, 130, 350-355. [CrossRef]

41. Costanza, R. Valuing Natural Capital and Ecosystem Services toward the Goals of Efficiency, Fairness, and Sustainability. Ecosyst. Serv. 2020, 43, 101096. [CrossRef]

42. Cho, M.; Kim, G. A Cross-Cultural Comparative Analysis of Crowdfunding Projects in the United States and South Korea. Comput. Hum. Behav. 2017, 72, 312-320. [CrossRef]

43. Cox, J.; Nguyen, T.; Thorpe, A.; Ishizaka, A.; Chakhar, S.; Meech, L. Being Seen to Care: The Relationship between Self-Presentation and Contributions to Online pro-Social Crowdfunding Campaigns. Comput. Hum. Behav. 2018, 83, 45-55. [CrossRef]

44. Herrero, Á.; Hernández-Ortega, B.; San Martín, H. Potential Funders' Motivations in Reward-Based Crowdfunding. The Influence of Project Attachment and Business Viability. Comput. Hum. Behav. 2020, 106. [CrossRef]

45. Wang, W.; He, L.; Wu, Y.J.; Goh, M. Signaling Persuasion in Crowdfunding Entrepreneurial Narratives: The Subjectivity vs Objectivity Debate. Comput. Hum. Behav. 2021, 114, 106576. [CrossRef]

46. Zhang, Y.; Tan, C.D.; Sun, J.; Yang, Z. Why Do People Patronize Donation-Based Crowdfunding Platforms? An Activity Perspective of Critical Success Factors. Comput. Hum. Behav. 2020, 112, 106470. [CrossRef]

47. Anglin, A.H.; Wolfe, M.T.; Short, J.C.; McKenny, A.F.; Pidduck, R.J. Narcissistic Rhetoric and Crowdfunding Performance: A Social Role Theory Perspective. J. Bus. Ventur. 2018, 33, 780-812. [CrossRef]

48. Bollaert, H.; Leboeuf, G.; Schwienbacher, A. The Narcissism of Crowdfunding Entrepreneurs. Small Bus. Econ. 2020, 55, 57-76. [CrossRef]

49. Bitterl, S.; Schreier, M. When Consumers Become Project Backers: The Psychological Consequences of Participation in Crowdfunding. Int. J. Res. Mark. 2018, 35, 673-685. [CrossRef]

50. Rodriguez-Ricardo, Y.; Sicilia, M.; López, M. What Drives Crowdfunding Participation? The Influence of Personal and Social Traits. Span. J. Mark. ESIC 2018, 22, 163-182. [CrossRef]

51. Mawdsley, E. From Billions to Trillions': Financing the SDGs in a World 'beyond Aid. Dialogues Hum. Geogr. 2018, 8, 191-195. [CrossRef]

52. Cumming, D.J.; Leboeuf, G.; Schwienbacher, A. Crowdfunding Cleantech. Energy Econ. 2017, 65, 292-303. [CrossRef]

53. United Nations. Citing \$2.5 Trillion Annual Financing Gap during SDG Business Forum Event, Deputy Secretary-General Says Poverty Falling Too Slowly I Meetings Coverage and Press Releases. Available online: https://www.un.org/press/en/2019 /dsgsm1340.doc.htm (accessed on 19 July 2020).

54. United Nations Secretary-General. Roadmap for Financing the 2030 Agenda for Sustainable Development Executive Summary. Roadmap Sustain. Financial Syst. 2019, 4, 15.

55. Pizzi, S.; Corbo, L.; Caputo, A. Fintech and SMEs Sustainable Business Models: Reflections and Considerations for a Circular Economy. J. Clean. Prod. 2021, 281, 125217. [CrossRef] 
56. Deng, X.; Huang, Z.; Cheng, X. FinTech and Sustainable Development: Evidence from China Based on P2P Data. Sustainability 2019, 11, 6434. [CrossRef]

57. Arner, D.W.; Buckley, R.P.; Zetzsche, D.A.; Veidt, R. Sustainability, FinTech and Financial Inclusion. Eur. Bus. Organ. Law Rev. 2020, 21, 7-35. [CrossRef]

58. Böckel, A.; Hörisch, J.; Tenner, I. A Systematic Literature Review of Crowdfunding and Sustainability: Highlighting What Really Matters. Manag. Rev. Q. 2020, 1-21. [CrossRef]

59. Morell, M.F.; Hidalgo, E.S.; Rodríguez, E. Goteo.Org Civic Crowdfunding and Match-Funding Data Connecting Sustainable Development Goals. Sci. Data 2020, 7, 1-10. [CrossRef]

60. Barrick, M.R.; Mount, M.K. The Big Five Personality Dimensions and Job Performance. Pers. Psychol. 1991, 44, 1-26. [CrossRef]

61. Marcus, J.; Roy, J. In Search of Sustainable Behaviour: The Role of Core Values and Personality Traits. J. Bus. Ethics 2019, 158, 63-79. [CrossRef]

62. Robert, K.W.; Parris, T.M.; Leiserowitz, A.A. What Is Sustainable Development? Goals, Indicators, Values, and Practice. Environ Sci. Policy Sustain. Dev. 2005, 47, 8-21. [CrossRef]

63. Burford, G.; Hoover, E.; Velasco, I.; Janoušková, S.; Jimenez, A.; Piggot, G.; Podger, D.; Harder, M.K. Bringing the “Missing Pillar" into Sustainable Development Goals: Towards Intersubjective Values-Based Indicators. Sustainability 2013, 5, 3035-3059. [CrossRef]

64. Andersson, P.A.; Erlandsson, A.; Västfjäll, D.; Tinghög, G. Prosocial and Moral Behavior under Decision Reveal in a Public Environment. J. Behav. Exp. Econ. 2020, 87, 101561. [CrossRef]

65. Weaver, R.D. Prosocial Behavior-Private Contributions to Agriculture's Impact on the Environment. Land Econ. 1996, 72, 231-247. [CrossRef]

66. Chen, Y.; Dai, R.; Yao, J.; Li, Y. Donate Time or Money? The Determinants of Donation Intention in Online Crowdfunding. Sustainability 2019, 11, 4269. [CrossRef]

67. Pietraszkiewicz, A.; Soppe, B.; Formanowicz, M. Go pro Bono Prosocial Language as a Success Factor in Crowdfunding. Soc. Psych. 2017, 48, 265-278. [CrossRef]

68. Bowlby, J. The Making and Breaking of Affectional Bonds. I. Aetiology and Psychopathology in the Light of Attachment Theory. Br. J. Psychiatry 1977, 130, 201-210. [CrossRef] [PubMed]

69. Kim, M.J.; Petrick, J.F. The Effect of Herding Behaviors on Dual-Route Processing of Communications Aimed at Tourism Crowdfunding Ventures. J. Travel Res. 2020. [CrossRef]

70. Diener, E. Assessing Subjective Well-Being: Progress and Opportunities. Soc. Indic. Res. 1994, 31, 103-157. [CrossRef]

71. Seligman, M.E.; Csikszentmihalyi, M. Positive Psychology. An Introduction. Am. Psychol. 2000, 55, 5-14. [CrossRef]

72. Engelbrecht, H.J. Natural Capital, Subjective Well-Being, and the New Welfare Economics of Sustainability: Some Evidence from Cross-Country Regressions. Ecol. Econ. 2009, 69, 380-388. [CrossRef]

73. Hall, C.M. Consumerism, Tourism and Voluntary Simplicity: We All Have to Consume, but Do We Really Have to Travel so Much to Be Happy? Tour. Recreat. Res. 2011, 36, 298-303. [CrossRef]

74. Membiela-Pollán, M.; Alló, M.; Pateiro-Rodríguez, C.; Blázquez-Lozano, F. The Inefficiency of the Neoclassical Paradigm in the Promotion of Subjective Well-Being and Socioeconomic, and Environmental Sustainability: An Empirical Test for the Spanish Case. Sustainability 2019, 11, 7102. [CrossRef]

75. Lengyel, A.; Kovács, S.; Müller, A.; Dávid, L.; Szoke, S.; Bába, É.B. Sustainability and Subjective Well-Being: How Students Weigh Dimensions. Sustainability 2019, 11, 6627. [CrossRef]

76. Kim, M.J.; Lee, C.K.; Bonn, M. Obtaining a Better Understanding about Travel-Related Purchase Intentions among Senior Users of Mobile Social Network Sites. Int. J. Inf. Manag. 2017, 37, 484-496. [CrossRef]

77. Kim, M.J.; Hall, C.M. A Hedonic Motivation Model in Virtual Reality Tourism: Comparing Visitors and Non-Visitors. Int. J. Inf. Manag. 2019, 46, 236-249. [CrossRef]

78. Kim, M.J.; Lee, C.K.; Preis, M.W. The Impact of Innovation and Gratification on Authentic Experience, Subjective Well-Being, and Behavioral Intention in Tourism Virtual Reality: The Moderating Role of Technology Readiness. Telemat. Inform. 2020, 49 , 101349. [CrossRef]

79. Zaini, S.H.R.; Akhtar, A. Modelling the Sustainable Development Goals for India-An Interpretive Structural Modelling Approach World Rev. Sci. Technol. Sustain. Dev. 2019, 15, 46-65. [CrossRef]

80. Cicchetti, D.V.; Shoinralter, D.; Tyrer, P.J. The Effect of Number of Rating Scale Categories on Levels of Inter-Rater Reliability: A Monte-Carlo Investigation. Appl. Psychol. Meas. 1985, 9, 31-36. [CrossRef]

81. Preston, C.C.; Colman, A.M. Optimal Number of Response Categories in Rating Scales: Reliability, Validity, Discriminating Power, and Respondent Preferences. Acta Psychol. 2000, 104, 1-15. [CrossRef]

82. Brislin, R.W. Back-Translation for Cross-Cultural Research. J. Cross-Cult. Psychol. 1970, 1, 185-216. [CrossRef]

83. Douglas, S.P.; Craig, C.S. Collaborative and Iterative Translation: An Alternative Approach to Back Translation. J. Int. Mark. 2007, 15, 30-43. [CrossRef]

84. Fricker, R.D.; Schonlau, M. Advantages and Disadvantages of Internet Research Surveys: Evidence from the Literature. Field Methods 2002, 14, 347-367. [CrossRef]

85. Wright, K.B. Researching Internet-Based Populations: Advantages and Disadvantages of Online Survey Research, Online Questionnaire Authoring Software Packages, and Web Survey Services. J. Comput. Commun. 2005, 10. [CrossRef] 
86. Kline, R.B. Principles and Practice of Structural Equation Modeling, 3rd ed.; The Guilford Press: New York, NY, USA, 2011.

87. Hair, J.F.; Black, W.C.; Babin, B.J.; Anderson, R.E. Multivariate Data Analysis, 8th ed.; Cengage: Andover, UK, 2019.

88. National Information Society Agency. Survey on Internet Use. Available online: https://www.nia.or.kr/site/nia_kor/ex/bbs/ List.do?cbIdx=99870 (accessed on 29 April 2020).

89. Lee, Y.S.; Lee, J.; Lee, K.T. Amounts of Responding Times and Unreliable Responses at Online Survey. Sur. Res. 2008, 9, 51-83.

90. Chin, W.W.; Marcolin, B.L.; Newsted, P.R. A Partial Least Squares Latent Variable Modeling Approach for Measuring Interaction Effects: Results from a Monte Carlo Simulation Study and Electronic-Mail Emotion/Adoption Study. Inf. Syst. Res. 2003, 14, 189-217. [CrossRef]

91. Hair, J.F.; Hult, G.T.M.; Ringle, C.; Sarstedt, M. A Primer on Partial Least Squares Structural Equation Modeling (PLS-SEM), 2nd ed.; Sage Publications: Thousand Oaks, CA, USA, 2017. [CrossRef]

92. Hair, J.F.; Sarstedt, M.; Ringle, C.M.; Mena, J.A. An Assessment of the Use of Partial Least Squares Structural Equation Modeling in Marketing Research. J. Acad. Mark. Sci. 2012, 40, 414-433. [CrossRef]

93. Ringle, C.M.; Wende, S.; Becker, J.M. SmartPLS 3.3.3. Available online: http:/ / www.smartpls.com (accessed on 14 September 2020).

94. Stevens, J. Applied Multivariate Statistics for the Social Sciences, 5th ed.; Lawrence Erlbaum Publishers: Mahwah, NJ, USA, 2009.

95. Fornell, C.; Larcker, D.F. Evaluating Structural Equation Models with Unobservable Variables and Measurement Error. J. Mark. Res. 1981, 18, 39-50. [CrossRef]

96. Geisser, S. A Predictive Approach to the Random Effect Model. Biometrika 1974, 61, 101-107. [CrossRef]

97. Stone, M. Cross-Validatory Choice and Assessment of Statistical Predictions. J. R. Stat. Soc. 1974, 36, 111-147. [CrossRef]

98. Sachs, J.D. Goal-Based Development and the SDGs: Implications for Development Finance. Oxf. Rev. Econ. Policy 2015, 31, 268-278. [CrossRef]

99. Hörisch, J. Take the Money and Run? Implementation and disclosure of environmentally-oriented crowdfunding projects. J. Clean. Prod. 2019, 223, 127-135. [CrossRef] 